[8] Pogarska, V., Pavlyuk, R., Tauber, R. D., Pogarskiy, A., Berestova, A., Kravchuk, T. et. al. (2017). Development of the extraction method of inactive forms of pectin substances from fruits to easy-digestible active form during the obtaining of nanofood. EUREKA: Life Sciences, 6, 57-64. doi: 10.21303/25045695.2017.00520

[9] Kirik, I. M. et. al. (2009). Parokonvektsionnyi apparat dlya ob"ektov obshhestvennogo pitaniya. Innovatsionnye tekhnologii v pishhevoy promyshlennosti, 394-401.

[10] Kutkina, M., Fedinishina, E. (2007). Parokonvektomat: znay i umey: rekomendatsii po teplovoy obrabotke kulinarnoy produktsii raznykh vidov. Pitanie i obshhestvo, 10, 10-12.

\title{
RESEARCH OF INFLUENCE OF POTASSIUM-RICH DIETS ON THE PHYSICAL PERFORMANCE OF STUDENTS
}

\author{
Olga Simakova \\ Department of technology in a restaurant economy that hotel and restaurant business \\ Donetsk National University of Economics and Trade named after M. I.Tugan-Baranovsky \\ 16 Tramvaina str., Kryvyi Rih, Ukraine, 50005 \\ Simakova@donnuet.edu.ua \\ Yurii Korenets \\ Department of technology in a restaurant economy that hotel and restaurant business \\ Donetsk National University of Economics and Trade named after M. I.Tugan-Baranovsky \\ 16 Tramvaina str., Kryvyi Rih, Ukraine, 50005 \\ korenets_y@donnuet.edu.ua \\ Tatiana Yudina \\ Department of Technology and the organization of restaurant business \\ Kyiv National University of Trade and Economics \\ 19 Kyoto, str., Kyiv, Ukraine, 02156 \\ olegdmu@rambler.ru \\ Iryna Nazarenko \\ Department of technology in a restaurant economy that hotel and restaurant business \\ Donetsk National University of Economics and Trade named after M. I.Tugan-Baranovsky \\ 16 Tramvaina str., Kryvyi Rih, Ukraine, 50005 \\ Nazarenko@donnuet.edu.ua \\ Iuliia Goriainova \\ Department of technology in a restaurant economy that hotel and restaurant business \\ Donetsk National University of Economics and Trade named after M. I.Tugan-Baranovsky \\ 16 Tramvaina str., Kryvyi Rih, Ukraine, 50005 \\ goryaynova@donnuet.edu.ua
}

\footnotetext{
Abstract

The aim of the work is the scientific substantiation and experimental support of the expedience and use of potassium-cationic water for improving the bread quality and the study of the influence of potassium-rich diets on the physical performance of students. There was studied the influence of potassium cations on the activity of proteolytic enzymes of wheat flour. It was established, that at using potassium-cationic water, the output of wet gluten $(35,1 \%)$ essentially increases, at that the output of dry one $(8,4 \%)$ decreases to the same extent that is a positive factor in the bakery technology. It was proved that enriching the vital medium of bakery yeast by potassium cations essentially activates their ability to hydrolysis of maltose that favors activation of the process of gassing (maltase activity - 35,1 min). The process of gassing influences the speed of dough-conduction and ready bread quality, especially volume $(357,7,100 \mathrm{~g} / \mathrm{ml})$, porosity $(79,1 \%)$ and crumb ability to compression (33,5 c.u.). It was established, that consumption of bread, pro-
} 
duced on potassium-cationic water, favors the strengthening of the heart muscle tone, improvement of the general condition of the organism, especially, physical endurance and performance.

Keywords: potassium-cationic water, bread, potassium, wheat flour, bakery yeast, physical performance.

\section{Introduction}

The most important extracellular cation that provides the stability of the osmotic pressure of biological liquids in human and animal organisms is sodium. For providing metabolic processes of an adult human, 0,6-3,5 $\mathrm{g}$ a day that contain 0,24-1,37 $\mathrm{g} \mathrm{Na}^{+}$are enough [1]. But according to long traditions, most part of the world population consumes $8-16$ f of salt [2]. The human organism is not adapted to the big amount of sodium, usually consumed since infancy. The excessive accumulation of sodium in the organism favors the retention of liquids, up to increasing the arterial pressure (salt hypertension), supporting inflammatory processes, it results in the energetic excretion of potassium by the kidneys. The increased content of potassium in liquid mediums of the organism results in penetrating $\mathrm{Na}^{+}$in cells. Water and calcium accumulate in cells, the concentration of potassium decreases at that. Cells of a vascular wall swell, lose elasticity, acquire the ability to spasms [3]. Among alimentary factors that favor the spread of hypertonic disease, the most important one is the long excessive consumption of kitchen salt that is why the hyposodium diet is used at treatment first of all. It is also recommended at chronic heart failure, nephropathies at pregnancy, diseases of joints [4]. But the experience demonstrate that long salt-less regimes are very severe for patients, so substitutes of salt are used for giving the usual taste of products and dishes without kitchen salt.

One of most known substitutes of salt is potassium chloride, used in dishes instead of sodium chloride. It was established, that enrichment of diets with potassium favors the arterial pressure decrease, even at the excessive supply of sodium [5]. At the same time potassium itself plays the very important role in the organism - it is in blood and in cytoplasm, participates in the metabolism of proteins and carbohydrates, is necessary for the normal work of muscles, especially heart one (myocardium) [6]. In this connection the enrichment of food rations with potassium is very important not only for a sick, but for healthy organism. But potassium chloride is not so suitable for it, because of its bitterish taste. Products with adding $\mathrm{KCl}$ have an unusual taste, so the problem of enriching products and dishes with potassium needs additional studies. The main source of potassium for the organism is plants that contain it in big amounts. Potassium cation in the plants' composition is bound with organic acids and doesn't have such taste defects as potassium chloride.

The human organism loses much potassium at physical loads, for example, at sports training. If not to replenish potassium, it may result in general physical weakness then in disorders in the heart muscle work. That is why sportsmen use a potassium-rich diet that contains bananas, grapes, apricots and so on. Last time, as a result of the very low quality of drinking water, one, cleaned of pollution by the cation-exchange method is used at producing food [7]. Despite the very high purification rate, this method has an essential defect - water is enriched with sodium cations at it. It results in shifting the sodium-potassium balance in the organism, decelerates water excretion from the organism and occasionally results in diseases, most often hypertonic one. This defect limits consumption of cationic water at producing food.

There is offered the method of ion-exchanging cleaning of water by passing through potassium-cationic filters, obtained by sorbent regeneration by potassium chloride instead of sodium chloride. At that water is enriched not by sodium cations but by potassium ones in concentration $172 \mathrm{mg} / \mathrm{g}$, according to the analysis. It makes such water treating-prophylactic already at direct consumption [8]. The use of potassium-cationic water at producing some food may favor the improvement of recipes of culinary products for treating-prophylactic nutrition [9]. At that products are also enriched with potassium cations and may be used in diets of sportsmen and workers, which specialties are connected with hard physical loads. At that it is possible to save much money, using usual products, made using potassium-cationic water, for example, bread instead of expensive, deficit rations of special destination. 
But before recommending water, prepared in such a way, for including in recipes of food products, it is necessary to be sure in its positive influence on food value and consumption qualities of these products. There was planned to study the influence of potassium-cationic water of the behavior of the protein complex of wheat flour. Biochemical changes of the complex at producing bread and other products of yeast dough under the effect of enzymes-proteases are responsible for food and consumption value essentially.

The aim of the work is the scientific substantiation and experimental support of the expedience and use of potassium-cationic water for improving the bread quality and the study of the influence of potassium-rich diets on physical performance of the human organism.

The following tasks were solved for achieving this aim:

- to study the influence of potassium cations on the activity of proteolytic enzymes of wheat flour;

- to determine the influence of potassium-cationic water on the maltase activity of bakery yeast and quality of ready products; organism.

- to study the influence of potassium-rich diets on the physical performance of the human

\section{Materials and Methods}

Research materials:

- wheat flour of the highest sort (“Dnipromlin” LTD, Ukraine);

- bakery yeast (PSC “Enzyme”, Ukraine);

- distilled water;

- potassium-cationic water;

- gluten, excreted from samples of wheat flour of the highest sort;

- bread, produced using potassium-rich water.

The influence of potassium cations on the activity of protheolytic enzymes of wheat flour was assessed by the output of wet and dry gluten of dough, made on potassium-cationic and distilled water. Gluten was washed from dough after keeping during 1,5 hours in the experiments.

The maltase activity was determined by Roiter method as a time (in minutes), in which $1 \mathrm{~g}$ of yeast releases $20 \mathrm{ml}$ of $\mathrm{CO}_{2}$ at reactions with the maltose solution [10].

For studying the influence of the potassium-rich diet on human health, the physical performance was studied in two groups of students of Donetsk national university of economy and trade at activities of physical culture. The experiments included only boys of the same age and almost same weight for decreasing the experiment error that surely appears because of different physical abilities of boys and girls. In one group the lunch of boys was added wit bread, baked on potassium-cationic water (test baking was conducted under laboratory conditions). The other group - control one, consumed usual bread. The total number of boys, who took part in the experiment, was 30 persons - 15 in each one. Observations were conducted during one month - two times a week at facultative activities on physical culture.

Determination of the physical performance using $\mathrm{PWC}_{170}$ test is based on two facts, wellknown in physiology of muscular activity:

- the heart rate increase at muscular work is directly proportional to its intensity;

- the degree of heart rate increase at any physical load (not maximal) is reversely proportional to the human ability to carry out the muscular work of the given intensity that is physical performance.

So, the heart rate (HR) at muscular work may be used as a reliable criterion of the human physical performance. In rather large diapason of intensities of physical loads, interrelations between HR and intensity are practically linear that gives a possibility for linear extrapolation at $\mathrm{PWC}_{170}$ calculationo by two relatively little loads. The linear dependence between HR and load intensity ends immediately after $170 \mathrm{beat} / \mathrm{min}$. At that $\mathrm{HR}=170 \mathrm{beat} / \mathrm{min}$ is optimal for heart work of a healthy human, because it is connected with maximal values of a striking blood volume (blood volume, thrown in the aorta at one heart contraction). The further HR increase results in the heart ejections decrease. 
For realizing this test, a student must not obligatory perform a hard load. It is enough to perform two moderate loads, separated by an interval of 5 minutes of rest. Each load lasts 5 minutes, during this time the cardiorespiratory system of the organism is reproduced. Immediately after the load, pulse is counted for 10 seconds and multiplied by $6-$ there is a result in beat $/ \mathrm{min}$. HR after the first load must reach 100-120 beat/min, and after second one $-145-160$ beat $/ \mathrm{min}$. The calculation of the physical performance is realized by the formula:

$$
\mathrm{PWC}_{170}=\mathrm{W}_{1}+\left(\mathrm{W}_{2}-\mathrm{W}_{1}\right) \cdot \frac{\left(170-\mathrm{P}_{1}\right)}{\mathrm{P}_{2}-\mathrm{P}_{1}},
$$

where $\mathrm{W}_{1}$ and $\mathrm{W}_{2}$ - intensities of first and second loads; $\mathrm{P}_{1}$ and $\mathrm{P}_{2}-\mathrm{HR}$ after first and second loads. Stepergometry is a simple and rather exact method of dosing loads. This work type is based on the modified climb on a short flight of stairs that allows to perform a load under any conditions at minimal shifts of the research object. It is very comfortable to use two autonomic wooden steps with height 10 and $40 \mathrm{~cm}$. The work intensity is regulated by both a step height and speed of climbing on it. It is necessary to know a weight of the object accurate to $100 \mathrm{~g}$. The intensity of the performed load is calculated by the formula:

$$
\mathrm{W}_{\mathrm{kgm} / \mathrm{min} .}=1,33 \cdot \mathrm{P} \cdot \mathrm{H} \cdot \mathrm{n}, \mathrm{kgm} / \mathrm{min} \text {, }
$$

where $\mathrm{P}$ - body mass, kg; $\mathrm{H}$ - step height, $\mathrm{cm} ; \mathrm{n}$ - number of climbs in $1 \mathrm{~min} ; 1,33$ - coefficient that includes the value of work at descending from the step.

\section{1. Experimental procedures}

There was determined the influence of potassium cations on the activity of protheolytic enzymes of wheat flour. It must be noted, that the protein complex of dough gluten at mixing is affected by enzymes-proteases. They hydrolyze proteins to free amino acids that enrich dough, give nitrogen nutrition to yeast and favor Maillard reaction. It results in formation of crispy brown crust of ready bread [11]. The results of studying the influence of potassium cations on the activity of protheolytic enzymes of wheat flour are presented in Table 1.

\section{Table 1}

Influence of potassium cations on the activity of protheolytic enzymes of wheat flour

\begin{tabular}{cccc}
\hline Studied sample & Output of wet gluten, $\%$ & Output of dry gluten, $\%$ & Extensibility, cm \\
\hline Distilled water (control) & 33,0 & 10,2 & 6,8 \\
Potassium-cationic water & $\mathbf{3 5 , 1}$ & $\mathbf{8 , 4}$ & 6,7
\end{tabular}

The most important recipe component at producing wheat bread is bakery yeast that includes maltase along with other enzymes. Maltase plays the very important role in bakery and fermenting production [12]. In the process of diastatic hydrolysis of flour starch, maltose disaccharide accumulates and then disintegrates in two glucose molecules. At the insufficient maltase activity, maltaose hydrolysis in yeast stops, sugars fermentation and gassing decelerate [13]. But if bakery yeast is a full-value living organism with its own metabolism, medium enrichment with potassium cations must positively influence sodium-potassium balance of yeast cells. So, the vital, especially, maltase activity too. There was realized the accelerated determination of maltase activity of bakery yeast, suspended in usual and potassium-cationic water by Roiter method [10]. The results of studying the maltase activity of yeasts are presented in Table 2 .

The process of gassing influences the speed of dough-conduction and ready bread quality, especially volume, porosity and crumb ability to compression [14]. For confirming the positive influence of potassium-cationic water on these quality parameters of the ready product, there were realized the additional studies of the dependence of parameters on recipe water type at taste baking. 
The results of studying the influence of potassium-cationic water on the quality of ready products at test baking are presented in Table 3 .

Table 2

Determination of maltase activity of yeast

\begin{tabular}{cc}
\hline Reactive medium & Maltase activity, min \\
\hline Usual water & 33,0 \\
Potassium-cationic water & 35,1
\end{tabular}

Table 3

Influence of potassium-cationic water on the quality of ready products

\begin{tabular}{cccc}
\hline \multirow{2}{*}{ Recipe water } & \multicolumn{3}{c}{ Parameter } \\
\cline { 2 - 4 } & Volume, $\mathbf{1 0 0} \mathbf{~ g / m l}$ & Porosity, $\%$ & Ability to compression, c.u. \\
\hline Usual water & 290,0 & 74,5 & 25,3 \\
Potassium-cationic water & 357,7 & 79,1 & 33,5
\end{tabular}

The level of physical performance is one of objective criteria of student's health. The high physical performance is an indicator of stable health, and on the contrary, low values are considered as a risk factor for health and precondition for decreasing realization of all intellectual possibilities of a student. For determining the physical performance, the following loads tests are used: veloergometry, stepergometry, running on a treadmill and other simple methods of determining the ability to loads, used in mass studies [15]. The most spread are tests that determine the physical performance by HR at performing a certain dosed load. The functional test, based on determining the intensity of a muscular load, at which HR increases up to $170 \mathrm{beat} / \mathrm{min}$, is defined as $\mathrm{PWC}_{170}$ test.

There were studied two groups of students at the beginning of the experiment, when the working group only started to consume bread, enriched with potassium cations. The indices of physical performance of students, who consumed bread, enriched with potassium, at the beginning of the experiment, are presented in Table 4.

Then the detail examination was carried out at each activity on physical culture two times a week in both groups. Data were processed by the aforesaid methodology. The mean value of physical performance was calculated each time. At the end of the month experiment data were summarized, results of the influence of consumption of bread, enriched with potassium on the physical performance of students are presented on Fig. 1.

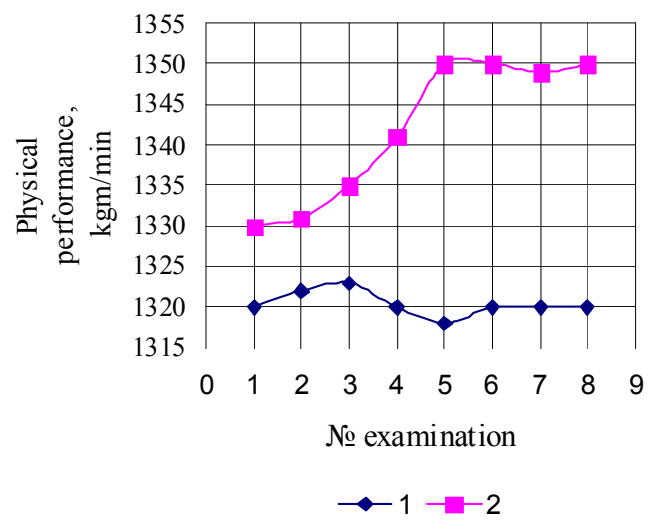

Fig. 1. Influence of consumption of bread, enriched with potassium on the physical performance of students: 1 - control group; 2 - working group 
Table 4

Indices of physical performance of students, who consumed bread, enriched with potassium, at the beginning of the experiment

\begin{tabular}{|c|c|c|c|c|c|c|c|c|c|c|c|}
\hline \multirow{2}{*}{$\begin{array}{c}\text { No. } \\
\text { object }\end{array}$} & \multirow{2}{*}{$\mathbf{P}, \mathbf{k g}$} & \multicolumn{2}{|c|}{$\mathrm{H}, \mathbf{c m}$} & \multirow[b]{2}{*}{$n_{1}$} & \multirow[b]{2}{*}{$\mathbf{n}_{2}$} & \multirow{2}{*}{$\begin{array}{c}\mathrm{HR}_{1} \\
\text { Beat/min }\end{array}$} & \multirow{2}{*}{$\begin{array}{c}\mathrm{HR}_{2} \\
\text { Beat/min }\end{array}$} & \multirow{2}{*}{$\begin{array}{c}\mathrm{W}_{1} \\
\mathrm{Kgm} / \mathrm{min}\end{array}$} & \multirow{2}{*}{$\begin{array}{c}\mathrm{W}_{2} \\
\mathrm{Kgm} / \mathrm{min}\end{array}$} & \multirow{2}{*}{$\begin{array}{l}\mathrm{PWC}_{170}, \\
\mathrm{Kgm} / \mathrm{min}\end{array}$} & \multirow{2}{*}{$\begin{array}{c}\text { Mean } \\
\text { value } \\
\text { PWC }_{170}\end{array}$} \\
\hline & & $\mathbf{H}_{1}$ & $\mathbf{H}_{2}$ & & & & & & & & \\
\hline \multicolumn{12}{|c|}{ Control group } \\
\hline 1 & 77,7 & 30 & 50 & 20 & 25 & 107 & 165 & 620 & 1292 & 1350 & \\
\hline 2 & 78,3 & 30 & 50 & 20 & 25 & 110 & 168 & 626 & 1302 & 1325 & \\
\hline 3 & 77,5 & 30 & 50 & 20 & 25 & 108 & 165 & 618 & 1288 & 1347 & \\
\hline 4 & 75,9 & 30 & 50 & 20 & 25 & 111 & 169 & 606 & 1262 & 1344 & \\
\hline 5 & 72,4 & 30 & 50 & 20 & 25 & 108 & 163 & 578 & 1204 & 1215 & \\
\hline 6 & 79,1 & 30 & 50 & 20 & 25 & 110 & 170 & 631 & 1315 & 1315 & \\
\hline 7 & 78,5 & 30 & 50 & 20 & 25 & 108 & 165 & 626 & 1305 & 1364 & \\
\hline 8 & 77,1 & 30 & 50 & 20 & 25 & 109 & 165 & 615 & 1282 & 1329 & 1320 \\
\hline 9 & 72,3 & 30 & 50 & 20 & 25 & 108 & 165 & 577 & 1202 & 1257 & \\
\hline 10 & 74,5 & 30 & 50 & 20 & 25 & 108 & 167 & 594 & 1238 & 1271 & \\
\hline 11 & 79,8 & 30 & 50 & 20 & 25 & 109 & 167 & 637 & 1327 & 1363 & \\
\hline 12 & 80,1 & 30 & 50 & 20 & 25 & 110 & 168 & 639 & 1332 & 1356 & \\
\hline 13 & 77,0 & 30 & 50 & 20 & 25 & 108 & 165 & 614 & 1280 & 1338 & \\
\hline 14 & 73,2 & 30 & 50 & 20 & 25 & 107 & 165 & 584 & 1217 & 1272 & \\
\hline 15 & 77,4 & 30 & 50 & 20 & 25 & 108 & 164 & 618 & 1287 & 1359 & \\
\hline \multicolumn{12}{|c|}{ Working group } \\
\hline 1 & 78,2 & 30 & 50 & 20 & 25 & 108 & 168 & 624 & 1300 & 1323 & \\
\hline 2 & 77,5 & 30 & 50 & 20 & 25 & 107 & 167 & 618 & 1288 & 1321 & \\
\hline 3 & 79,7 & 30 & 50 & 20 & 25 & 109 & 165 & 636 & 1325 & 1386 & \\
\hline 4 & 79,9 & 30 & 50 & 20 & 25 & 107 & 168 & 638 & 1328 & 1351 & \\
\hline 5 & 77,1 & 30 & 50 & 20 & 25 & 111 & 165 & 615 & 1281 & 1343 & \\
\hline 6 & 77,5 & 30 & 50 & 20 & 25 & 110 & 168 & 618 & 1288 & 1311 & \\
\hline 7 & 74,2 & 30 & 50 & 20 & 25 & 108 & 165 & 592 & 1233 & 1321 & \\
\hline 8 & 73,4 & 30 & 50 & 20 & 25 & 109 & 164 & 586 & 1220 & 1289 & 1330 \\
\hline 9 & 77,5 & 30 & 50 & 20 & 25 & 107 & 165 & 618 & 1288 & 1346 & \\
\hline 10 & 79,8 & 30 & 50 & 20 & 25 & 109 & 167 & 637 & 1327 & 1363 & \\
\hline 11 & 78,1 & 30 & 50 & 20 & 25 & 110 & 168 & 623 & 1298 & 1321 & \\
\hline 12 & 77,3 & 30 & 50 & 20 & 25 & 108 & 165 & 617 & 1285 & 1344 & \\
\hline 13 & 77,3 & 30 & 50 & 20 & 25 & 107 & 164 & 617 & 1285 & 1355 & \\
\hline 14 & 74,8 & 30 & 50 & 20 & 25 & 108 & 165 & 597 & 1244 & 1301 & \\
\hline 15 & 75,1 & 30 & 50 & 20 & 25 & 108 & 167 & 599 & 1248 & 1281 & \\
\hline
\end{tabular}

The data of Fig. 1 testify that the physical activity of the control group varies near the mean value, sometimes deviating, probably, because of the individual condition of each student in the given period of time. Curve 2 rather reliably indicates the continuous growth of the physical performance of students at consuming products, enriched with potassium, as it was expected, taking into account the influence of potassium cations on the myocardium tonus. So, products, prepared on potassium-cationic water acquire the increased concentration of potassium cations. Potassium cations are bound with organic substances of products and are very easily assimilated that results in increasing the general physical condition of the organism, especially physical endurance and performance. 


\section{Results}

It was established (Table 1), that at using potassium-cationic water, the output of wet gluten essentially increases, at that the output of dry one $(8,4 \%)$ decreases to the same extent. It is explained by the fact that potassium cations probably influence gluten hydration positively. Protein molecules in the reaction mixture acquire such conformation, at which hydrophilic functional groups become accessible for forming hydrogenous connections with water. Water, in its turn, is firmly retained by the whole protein complex. It is very positive process in baking technology, highly appreciated by technologists. For increasing the gluten ability to hydration, works for searching supplements that would provide easy binding of water by gluten protein molecules are realized throughout the world. Such effect of potassium cations is natural, because their less ability to hydration comparing with sodium is known [16]. In such situation this cation demonstrates the less competitive ability at fighting for water molecules together with a protein one, where the last one is preferential. The decrease of the output of dry gluten testifies to the activation of hydrolytic processes in dough. They result in the growth of monosaccharides and amino acids in a dough semi-product that conditions the ripening speed of yeast dough [17].

The obtained experimental data (Table 2) testify that enriching the vital medium of bakery yeast with potassium cations essentially activates their ability to maltose hydrolysis. As a result of maltose hydrolysis, the reactive mixture is enriched with glucose that gives nutrition to yeast and favors the activation of the gassing process.

The obtained data (Table 3) testify to the essential improvement of the quality of ready bread, prepared using water, enriched with potassium and are fully agreed with the previous experiments. Thus, the gassing growth as a result of increasing the maltase activity of yeast results in getting more bulky product with lush porous crumb with more elasticity.

So, potassium-cationing of water, used at bread production, allows to protect products from toxic heavy metals. Water, without any additional supplements allows to improve the quality of ready bread and to enrich it with such biogenic element as potassium. Consumption of such bread can essentially improve the tone of the cardiac muscle that must raise the physical performance and genera health of a human.

The data of table 4 testify that the physical performance of all students is almost equal due to the almost equal body mass and equal physical training. It is testified by mean arithmetical values of this parameter. They don't essentially differ in both groups.

It was established (Fig. 1) that indices of physical performance in the control group are approximated to the mean value, sometimes non-essentially deviating, probably, because of an individual condition of each student in the given period of time. The data (curve 2) testify to the steady growth of students' physical performance at consuming the product, enriched with potassium that may be explained by the influence of potassium cations on the myocardium tone.

Thus, products, prepared on potassium-cationic water acquire the increased concentration of potassium cations. They are bound with organic substances of a product and are very easily assimilated that results in improving the general condition of the organism, especially physical endurance and performance.

The prospects of further researches are studies of the influence of potassium-rich diets on sportsmen's physical endurance.

\section{Conclusions}

1. There was studied the influence of potassium cations on the activity of proteolytic enzymes of wheat flour. It was established, that at using potassium-cationic water, the output of wet gluten $(35,1 \%)$ essentially increases, at that the output of dry one $(8,4 \%)$ decreases to the same extent that is a positive factor in the bakery technology.

2. It was proved that enriching the vital medium of bakery yeast by potassium cations essentially activates their ability to hydrolysis of maltose that favors activation of the process of gassing (maltase activity - 35,1 min). The process of gassing influences the speed of dough-conduction and ready bread quality, especially volume $(357,7,100 \mathrm{~g} / \mathrm{ml})$, porosity $(79,1 \%)$ and crumb ability to compression (33,5 c.u.). 
3. It was established, that consumption of bread, produced on potassium-cationic water, favors the strengthening of the heart muscle tone, improvement of the general condition of the organism, especially, physical endurance and performance.

\section{References}

[1] Drozdova, T. M., Vloshhinskiy, P. E., Poznyakovskiy, V. M. (2012). Fiziologiya pitaniya. Moscow: DeLi plyus, 352 .

[2] Teplov, V. I., Boryaev, V. E. (2013). Fiziologiya pitaniya. Moscow: Dashkov i K, 452.

[3] Budennyi, M. M., Agarkov, V. V., Len'shin, V. N. (2010). Potrebitelyu o pit'evoy vode. Kharkiv: Faktor, 112.

[4] Blinkova, L. N., Efimenko, N. V., Topuriya, D. I. et. al. (2008). Novye tekhnologii korrektsii nedostatochnosti pitaniya v praktike vracha-dietologa. Voprosy kurortologii, fizioterapii i lechebnoy fizicheskoy kul'tury, 4, 37-39.

[5] Anderson, J. W., Tietyn-Clark, J. T. (1986). Dietary fiber: hyperlipidemia, hypertension and coronary artery-disease. The American Journal of Gastroenterology, 81 (10), 907-919.

[6] Korenets, Y., Goriainova, I., Nykyforov, R., Nazarenko, I., Simakova, O. (2017). The study of influence of aronia additives on functional-technological properties of wheat flour. EUREKA: Life Sciences, 1, 27-34. doi: 10.21303/2504-5695.2017.00299

[7] Brown, L., Rosner, B., Willett, W. W., Sacks, F. M. (1999). Cholesterol-lowering effects of dietary fiber: a meta-analysis. The American Journal of Clinical Nutrition, 69 (1), 30-42. doi: 10.1093/ajcn/69.1.30

[8] Voloshyn, M. D., Kriukovska, O. A., Ivanchenko, A. V. (2013). Problemy pidvyshchennia yakosti pytnoi vody. Dniprodzerzhynsk: DDTU, 268.

[9] Simakova, O., Nazarenko, I. (2017). Investigation of the impact of the qualitu of drinking water on the process of bread production. Bulletin of the National Technical University «KhPI» Series: New Solutions in Modern Technologies, 32 (1254), 112-116. doi: 10.20998/2413-4295.2017.32.18

[10] Anikeeva, N. V. (2012). Nauchnoe obosnovanie i razrabotka tekhnologiy khlebobulochnykh izdeliy funktsional'nogo znacheniya. Zhurnal Vestnik Altayskogo gosudarstvennogo agrarnogo universiteta, $1,77-81$.

[11] Tankyan, S. W. (2013). Characterization of drinkink water for baking industry. Biochemistry of baking, 19-36.

[12] Wasser für Backen (2009). Available at: http://orgprints.org/8714/1/wasser_f\%C3\%BCr_ backen.pdf

[13] Chang, J., Ksiu, W. (2011). Enzymes and their effect on the quality of dough. Food Sciences, 15 (4), 33-37.

[14] Katalinic, V., Milos, M., Kulisic, T., Jukic, M. (2006). Screening of 70 medicinal plant extracts for antioxidant capacity and total phenols. Food Chemistry, 94 (4), 550-557. doi: 10.1016/j.foodchem.2004.12.004

[15] Simakova, O., Korenets, Y., Glushko, V. (2016). Research and effect of drinking water on bread-making properties of wheat flour. Bulletin of the National Technical University «KhPI» Series: New Solutions in Modern Technologies, 25 (1197), 158-163. doi: 10.20998/2413-4295.2016.25.23

[16] Simakova, O. O. (2012). Vplyv vody na yakist khliba. Swordl. Tekhnichni nauky, 10, 88-90.

[17] Sanamian, K. Yu. (2001). Water chemical reactions and their effect on quality of wheat flour baking products. Journal of Food Biochemistry, 19 (8), 645-651. 